\title{
An improved non-cryogenic transport and storage preservative facilitating DNA extraction from 'difficult' plants collected at remote sites
}

\author{
John A. Thomson
}

\begin{abstract}
Thomson, J.A. (National Herbarium of NSW, Royal Botanic Gardens, Sydney, NSW 2000, Australia) 2002. An improved non-cryogenic transport and storage preservative facilitating DNA extraction from 'difficult' plants collected at remote sites. Telopea 9(4): 755-760. Addition of $200 \mathrm{mM}$ sodium ascorbate as an antioxidant to Rogstad's saturated $\mathrm{NaCl}-\mathrm{CTAB}$ preservative extends the range of plant species from which good-quality DNA can be obtained without cryogenic transport and storage. The improved preservative is conveniently sent to collectors as a pre-weighed dry mix requiring only the addition of hot water.
\end{abstract}

\section{Introduction}

DNA of size and purity suitable for restriction analysis, cloning and selective sequence amplification using the polymerase chain reaction (PCR) is now routinely obtainable from most plant species if fresh, cryogenically stored, or freeze dried tissue at appropriate developmental stages is available. However, studies concerned with phylogenetic relationships, or with genetic resources and diversity, often depend on gathering, storage and transport of plant samples in remote localities where cryogenic facilities are unavailable. In such cases, procedures involving desiccation (Doyle \& Dickson 1987) especially with silica gel (Chase \& Hills 1991) and calcium sulphate (Liston et al. 1990), or pickling in NaCl-CTAB (saturated brine containing cetyl trimethylammonium bromide detergent/disinfectant; Rogstad 1992) have dramatically improved success rates in obtaining workable DNA. Nevertheless, there remain many intransigent species for which current non-cryogenic methods have proved inadequate.

Problems in obtaining good quality DNA are generally greatest when working with leaves or shoots rich in resins, mucilage/gums, and polyphenolics/tannins (Katterman \& Shattuck 1983; Rogers \& Bendich 1985; Pyle \& Adams 1989; Couch \& Fritz 1990; Rowland \& Nguyen 1993). Major difficulties centre on irreversible cross-linking of DNA, often accompanied by the formation of pigmented adducts, and the tanning of chromosomal proteins to form an insoluble matrix from which only short DNA fragments, unsuitable for restriction analysis or for use as amplification templates, can be extracted. These processes commence with extreme rapidity, even at low temperatures (Couch \& Fritz 1990), when cells are damaged by cutting and bruising during leaf harvest, and compartmentalisation breaks down (Loomis 1974). In addition, polyphenolics/polysaccharides that co-extract with DNA (Katterman \& Shattuck 1983) may subsequently affect activity of processing enzymes such as restriction nucleases and Taq DNA polymerase (Štorchová et al. 2000).

During phylogenetic studies of ferns (Family Dennstaedtiaceae; Thomson 2000), tests of field-drying (Liston et al. 1990; Chase \& Hills 1991) resulted in low yields of discoloured DNA of short fragment lengths. Preservation in NaCl-CTAB (Rogstad 1992) proved better, although DNA yields were variable and of unreliable quality. The 
addition to $\mathrm{NaCl}-\mathrm{CTAB}$ solution of an antioxidant such as sodium ascorbate is shown here to reduce degradative changes affecting the quality of DNA subsequently extracted from stored leaf tissue.

\section{Materials and methods}

Variables relating to the collection, storage, and DNA extraction in NaCl-CTAB based leaf preservative with and without $200 \mathrm{mM} \mathrm{Na}$ ascorbate as an antioxidant were assessed using field collected samples of bracken fern, Pteridium esculentum (G. Forst.) Cockayne from New South Wales, Australia, and of Paesia scaberula (A. Rich.) Kuhn from Auckland, New Zealand (Dennstaedtiaceae). Additional trials of the preservative containing $\mathrm{Na}$ ascorbate employed leaves of the monocotyledons Anarthria humilis Nees (Anarthriaceae) as well as photosynthetic stems of both Georgeantha hexandra B.G. Briggs and L.A.S. Johnson (Ectdeiocoleaceae) and Alexgeorgea subterranea Carlquist (Restionaceae). For the dicotyledon Persoonia acicularis F. Muell. (Proteaceae), the needle-like leaves were used.

The modified leaf preservative was provided to collectors as a pre-weighed drypowder mix in square, autoclavable, leakproof, screwcap bottles of polypropylene (Style 2110, Nalge Company, Rochester, NY) of $60 \mathrm{ml}$ or $175 \mathrm{ml}$ capacity. Bottles were marked on the outside to indicate content levels of 50 or $150 \mathrm{ml}$ respectively. Contents of the $60 \mathrm{ml}$ bottles for $50 \mathrm{ml}$ of preservative were $20 \mathrm{~g} \mathrm{NaCl}, 2 \mathrm{~g} \mathrm{Na}$ ascorbate, $1.5 \mathrm{~g}$ CTAB, $2 \mathrm{~g}$ silica gel desiccant; pro rata for $175 \mathrm{ml}$ bottles to contain $150 \mathrm{ml}$ of preservative. Silica gel desiccant was included to ensure the long-term stability of dry leaf-preservative mix not required for immediate use: uptake of moisture under humid conditions allows rapid oxidation of sodium ascorbate in air. Desiccant should be omitted if the leaf preservative is to be used promptly.

At least one day before the leaf preservative is required for use, freshly boiled hot water of drinking quality was added up to the indicated levels for the required number of bottles. Depending on the quality of the water available, sufficient boiling (>5 min) was recommended to achieve de-aeration, and as far as possible, demineralisation. The contents were stirred occasionally and tilted or rocked from side to side during cooling to facilitate dissolution. Shaking was avoided so as to minimise foaming and re-aeration.

For larger leaf samples, a single 60 or $175 \mathrm{ml}$ bottle was used for each plant as appropriate. For smaller samples, the cooled preservative was aliquotted into appropriate vials. Leaves were cut as quickly as possible on site into pieces free from major veins and of suitable size to fit the container with minimal crushing and bruising, not exceeding one part of tissue to about four parts of preservative. A pencilled label on waterproof synthetic paper and a square of nylon or cellulose gauze was placed over the sample to keep it submerged in the preservative. Samples were kept in darkness at ambient temperature away from local heat sources for transport to the laboratory and storage over periods up to 6 months.

Soft, just unfurled bracken pinnae were preserved contemporaneously in both Rogstad's (1992) original NaCl-CTAB solution and in the modified formulation containing $200 \mathrm{mM}$ Na ascorbate. Prior to DNA extraction 1, 2, 5, 10, 25, 50 and 100 weeks after collection, leaf pieces were thoroughly washed in cool tap water flowing through a nylon sieve, rinsed in distilled water and blotted dry. Two approaches to DNA extraction were used. The first employed Rogstad's (1992) double grinding protocol, involving an initial hot CTAB extraction after pulverisation using liquid 
nitrogen, followed by regrinding with sand in the same buffer and re-incubation. The second method (Štorchová et al. 2000) utilised preliminary homogenisation of the leaf tissue in extraction buffer [0.34M sorbitol, $0.1 \mathrm{M}$ Tris- $\mathrm{HCl}$ at $\mathrm{pH} 7.6,5 \mathrm{mM}$ EDTA, $1.0 \% \mathrm{v} / \mathrm{v} 2$-mercaptoethanol] to remove polyphenolics, polysaccharides and other potentially interfering compounds before hot-CTAB extraction of DNA from the cellular residue. Crude DNA prepared by both approaches was assayed for fragment length and relative yield by agarose-gel using appropriate DNA standards. After final purification by silica binding, template competence of each DNA was assessed in PCRs. For Dennstaedtiaceae, multiple AP-PCR primers were used (Thomson 2000). For other species, amplification of the chloroplast trn L intron and trn L -trn F spacer (Taberlet et al. 1991) was tested.

\section{Results and discussion}

Darkening of bracken pinnulets close to the surface of $\mathrm{NaCl}-\mathrm{CTAB}$ preservative not containing antioxidant was evident 12-24 hr after collection. Discolouration developed progressively with time, from the preservative meniscus downwards, for at least 4-6 weeks after collection. By this time many of the uppermost pinnulets in the preservative were brownish-green in colour. Pinnulets preserved in $\mathrm{NaCl}-\mathrm{CTAB}$ containing $200 \mathrm{mM} \mathrm{Na}$ ascorbate remained light yellowish-green more than 2 years after collection. Some batches of ascorbate-containing preservative that had been made up using household salt developed a brownish discoloration in the storage medium over time, apparently due to decomposition of sodium or potassium ferrocyanide frequently present as an anti-caking agent in such salt. DNA extracted from these samples showed no apparent adverse effect.

Precise comparative evaluation of the yield and quality of DNA extracted from leaf samples is difficult due to between-sample variation reflecting differences in developmental age, physiological condition and handling (cutting, bruising, squashing) that may affect even different parts of the same lamina. Variability in the time taken to process samples, grinding pressure, temperature and shaking during extraction as well as deproteinisation efficiency also influence recovery of DNA.

The results of DNA extraction from bracken pinnae of comparable age and condition that had been silica-gel dried or pickled in either Rogstad's NaCl-CTAB or $\mathrm{NaCl}-\mathrm{CTAB}-200 \mathrm{mM} \mathrm{Na}$ ascorbate are summarised in Table 1, with data for DNA extracted from freshly collected or freeze-dried tissue for comparison. Concomitant with the discoloration of bracken pinnulets in unmodified NaCl-CTAB, DNA extracted from this tissue became increasingly yellowish to brownish-yellow in colour over the first 5 weeks of storage, with a progressive decrease in the proportion of DNA of fragment length $>20 \mathrm{~kb}$ (Table 1) and a parallel reduction in the success rate for AP-PCR with a range of primers (Thomson 2000) evident after clean up of the DNA by silica binding. In contrast, consistent yields of uncoloured DNA with fragment lengths predominantly about $25 \mathrm{~kb}$ were obtained from bracken pinnulets stored at room temperature in NaCl-CTAB- $200 \mathrm{mM}$ Na ascorbate for at least 25 weeks, and for at least 2 years when stored at $-20^{\circ} \mathrm{C}$ after initial equilibration in preservative at ambient temperatures (cf. Rogstad 1992). Extraction of samples preserved in $\mathrm{NaCl}-$ CTAB-ascorbate using the method of Štorchová et al. (2000), without grinding under liquid $\mathrm{N}_{2}$, typically resulted in slightly higher yields of DNA of longer fragment length than those obtained after grinding in liquid $\mathrm{N}_{2}$. After clean up by silica binding, DNA from pinnae preserved in $\mathrm{NaCl}-\mathrm{CTAB}$-ascorbate consistently amplified successfully in PCRs (Table 1). 
Table 1. The effect of tissue preservation and storage conditions on DNA extracted from young pinnae of sporophytes of Pteridium esculentum

\begin{tabular}{|c|c|c|c|c|}
\hline \multirow[t]{2}{*}{ Conditions } & \multicolumn{4}{|c|}{ Extracted DNA } \\
\hline & Yield & Colour & Length ${ }^{1}$ & $\mathbf{P C R}^{2}$ \\
\hline 1. Fresh tissue, liquid $\mathrm{N}_{2}$ & high & white & $>25$ & reliable \\
\hline 2. Dried in silica gel ${ }^{3}$, liquid $N_{2}$ & low & yellow & $0.5-5$ & useless \\
\hline 3. Freeze dried, dry milled & high & white & $>25$ & reliable \\
\hline \multicolumn{5}{|l|}{ 4. $\mathrm{NaCl}-\mathrm{CTAB}$ unmodified ${ }^{3}$, liquid $\mathrm{N}_{2}$} \\
\hline 1 week & low & yellow & 20 & variable \\
\hline 2 weeks & very low & orange & $15-20$ & poor \\
\hline 5 weeks or more & very low & brownish & $0.5-10$ & useless \\
\hline \multicolumn{5}{|l|}{ 5. $\mathrm{NaCl}-\mathrm{CTAB}$-ascorbate ${ }^{4}$, liquid $\mathrm{N}_{2}$} \\
\hline $1-100$ weeks, ground $\times 1$ & low & white & $>25$ & reliable \\
\hline $1-100$ weeks, ground $\times 2$ & moderate & white & $>20$ & reliable \\
\hline \multicolumn{5}{|l|}{ 6. $\mathrm{NaCl}-\mathrm{CTAB}$-ascorbate ${ }^{4}$, sorbitol ${ }^{5}$} \\
\hline $1-100$ weeks & moderate & white & $>25$ & reliable \\
\hline
\end{tabular}

${ }^{1}$ predominant fragment length in kb estimated using gel electrophoresis; ${ }^{2}$ ability to serve as template for PCR after standard clean up by silica binding; ${ }^{3 k e p t}$ at ambient temperature; ${ }^{4}$ kept at ambient temperature up to 10 weeks, then $-20^{\circ} \mathrm{C} ;{ }^{5}$ method of Štorchová et al. (2000).

DNA obtained from samples of Alexgeorgea, Anarthria, Georgeantha and Persoonia stored for approximately 4 weeks in $\mathrm{NaCl}-\mathrm{CTAB}$-ascorbate in each case supported successful PCR amplification of the chloroplast trn L intron and trn L-trn F spacer sequence (cf. Štorchová et al. 2000). In DNA studies of the Casuarinaceae, use of the $\mathrm{NaCl}-\mathrm{CTAB}$-ascorbate preservative has provided markedly improved reliability and product quality when compared with material dried in silica gel (Steane \& Wilson pers. comm. 2001).

In situ damage to DNA in leaf tissue harvested for non-cryogenic storage can be minimised by avoiding more cutting and bruising than is essential to facilitate dehydration (as when using silica gel; Štorchová et al. 2000) or for cellular exposure to $\mathrm{NaCl}-\mathrm{CTAB}$ (especially when preserving leaves with thick cuticles). Attention to minimising exposure of damaged tissue to air during transfer to $\mathrm{NaCl}-\mathrm{CTAB}$, and avoiding re-aeration of the preservative solution by shaking and frothing may also be helpful. Nickrent (1994) advocated addressing problems associated with non-cryogenic storage and transport by homogenising leaves in the field immediately after collection in buffered $\mathrm{NaCl}-\mathrm{CTAB}$ containing antioxidants at $95^{\circ} \mathrm{C}$, then incubating at $70-80^{\circ} \mathrm{C}$ for $30 \mathrm{~min}$ prior to transport and short-term storage at ambient temperatures. This treatment presumably both denatures the enzymes responsible for oxidative processes detrimental to DNA yield and quality, and also destroys deoxynucleases. However, as Storchová et al. (2000) point out, this approach is not generally suitable for remote site collecting, especially as collecting of rare species may be necessarily opportunistic and/or may depend on collectors unpractised in such laboratory techniques.

Antioxidant additives, such as ascorbate at concentrations of 50-200 mM (Wendel \& Weeden 1990), are effective in controlling loss of enzyme activity during preparation 
of plant tissue extracts for isozyme studies (Loomis 1974; Kephart 1990; Wendel \& Weeden 1990). This suggested the approach adopted here of including an antioxidant in Rogstad's saturated NaCl-CTAB preservative for plant tissue to be used for DNA extraction. Choice of $\mathrm{Na}$ ascorbate reflects its wide use in current DNA extraction buffers (e.g. Chase \& Hills 1991; Nickrent 1994), low cost, stability during dry storage, heat decomposition temperature $\left(218^{\circ} \mathrm{C}\right)$ compatible with the use of hot water to facilitate making up the preservative solution, and its relative stability at the $\mathrm{pH}$ of $\mathrm{NaCl}-\mathrm{CTAB}$ solutions (about $\mathrm{pH}$ 5.5-6.0; $\mathrm{Na}$ ascorbate solutions oxidise readily in contact with air at $\mathrm{pH}>7)$.

Due to the bactericidal and detergent properties of CTAB, NaCl-CTAB field preservation not only avoids bacterial or fungal proliferation during relatively prolonged dehydration in air, but also facilitates careful cleaning of leaves during washing in the laboratory before DNA extraction.

The problems of poor DNA extractability after pickling in $\mathrm{NaCl}-\mathrm{CTAB}$, and the release into grinding buffers of high levels of polyphenolics, polysaccharides and other interfering substances including inhibitors of DNA processing enzymes, are effectively countered by preliminary homogenisation in a sorbitol wash buffer before hot CTAB extraction of DNA (Štorchová et al. 2000). These authors have shown that such a sorbitol-buffer wash extracts many polyphenolics, polysaccharides and other interfering substances without significant loss of DNA from the fragmented cellular material. Using the sorbitol-wash method, the yield of good quality DNA extracted from bracken fronds stored in $\mathrm{NaCl}-\mathrm{CTAB}$ containing antioxidant was at least equal to that obtained with Rogstad's (1992) double-grinding procedure, and was more consistent from sample to sample.

When coupled with improvements to DNA extraction proposed by Štorchová et al. (2000), the addition of $200 \mathrm{mM}$ Na ascorbate to Rogstad's saturated NaCl-CTAB leaf preservative increases opportunities for DNA studies of 'difficult' plant species from remote sites, especially those which may be available only opportunistically.

\section{Acknowledgments}

I thank Barbara Briggs, Surrey Jacobs, Peter Weston and Karen Wilson for helpful comments, field-collecting at remote sites, and plant identifications. Adam Marchant and Carolyn Porter extracted and tested DNA from the angiosperm samples.

\section{References}

Chase, M.W. \& Hills, H.H. (1991) Silica gel: an ideal material for field preservation of leaf samples for DNA studies. Taxon 40: 215-220.

Couch, J.A. \& Fritz, P.J. (1990) Isolation of DNA from plants high in polyphenolics. Plant Mol. Biol. Rep. 8: 8-12.

Doyle, J.J. \& Dickson, E.E. (1987) Preservation of plant samples for DNA restriction endonuclease analysis. Taxon 36: 715-722.

Katterman, F.R.H. \& Shattuck, V.I. (1983) An effective method of DNA isolation from the mature leaves of Gossypium species that contain large amounts of phenolic terpenoids and tannins. Prep. Biochem. 13: 347-359.

Kephart, S.R. (1990) Starch gel electrophoresis of plant enzymes: a comparative analysis of techniques. Amer. J. Bot. 77: 693-712.

Liston, A., Rieseberg, L.D., Adams, R.P., Do, M. \& Zhu, G. (1990) A method for collecting dried plant specimens for DNA and isozyme analyses and the results of a field test in Xinjiang, China. Ann. Missouri Bot. Gard. 77: 859-863. 
Loomis, W.D. (1974) Overcoming problems of phenolics and quinones in the isolation of plant enzymes and organelles. Methods Enzymol. 31: 528-544.

Nickrent, D.L. (1994) From field to film: rapid sequencing methods for field-collected plant species. BioTechniques 16: 470-472, 474-475.

Pyle, M.M. \& Adams, R.P. (1989) In-situ preservation of DNA in plant specimens. Taxon 38: $576-581$.

Rogers, S.O. \& Bendich, A.J. (1985) Extraction of DNA from milligram amounts of fresh, herbarium and mummified plant tissues. Plant Mol. Biol. 5: 69-76.

Rogstad, S.H. (1992) Saturated NaCl-CTAB solution as a means of field preservation of leaves for DNA analyses. Taxon 41: 701-708.

Rowland, L.J. \& Nguyen, B. (1993) Use of polyethylene glycol for purification of DNA from leaf tissue of woody plants. BioTechniques 14: 735-736.

Štorchová, H., Hrdličková, R., Chrtek, J., Tetera, M., Fitze, D. \& Fehrer, J. (2000) An improved method of DNA isolation from plants collected in the field and conserved in saturated $\mathrm{NaCl} / \mathrm{CTAB}$ solution. Taxon 49: 79-84.

Taberlet, P., Gielly, L., Patou, G. \& Bouvert, J. (1991) Universal primers for amplification of three non-coding regions of chloroplast DNA. Plant Mol. Biol. 17: 1105-1109.

Thomson, J.A. (2000) Morphological and genomic diversity in the genus Pteridium (Dennstaedtiaceae). Ann. Bot. 85 (Suppl. B): 77-99.

Wendel, J.F. \& Weeden, N.F. (1990) Visualisation and interpretation of plant isozymes. Pp. 5-45 in Soltis, D.F. \& Soltis, P.S. (eds), Isozymes in Plant Biology. (Chapman and Hall: London). 